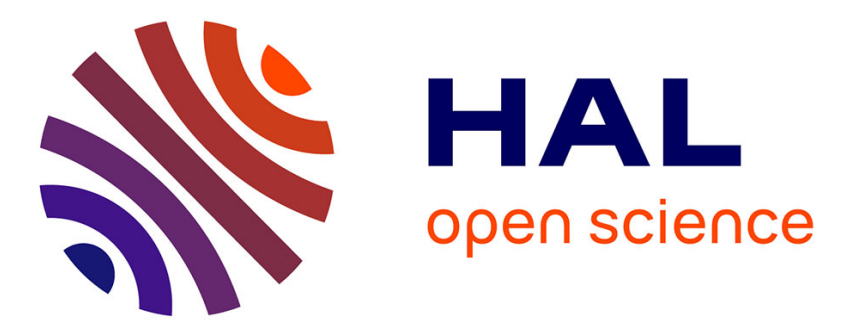

\title{
Fluorinated carbon blacks: influence of the morphology of the starting material on the fluorination mechanism
}

\author{
Alain Tressaud, T. Shirasaki, Gérard Nansé, Eugène Papirer
}

\section{To cite this version:}

Alain Tressaud, T. Shirasaki, Gérard Nansé, Eugène Papirer. Fluorinated carbon blacks: influence of the morphology of the starting material on the fluorination mechanism. Carbon, 2002, 40 (2), pp.217-220. 10.1016/S0008-6223(01)00177-4 . hal-00071049

\section{HAL Id: hal-00071049 \\ https://hal.science/hal-00071049}

Submitted on 30 May 2012

HAL is a multi-disciplinary open access archive for the deposit and dissemination of scientific research documents, whether they are published or not. The documents may come from teaching and research institutions in France or abroad, or from public or private research centers.
L'archive ouverte pluridisciplinaire HAL, est destinée au dépôt et à la diffusion de documents scientifiques de niveau recherche, publiés ou non, émanant des établissements d'enseignement et de recherche français ou étrangers, des laboratoires publics ou privés. 


\title{
Fluorinated carbon blacks : influence of the morphology of the starting material on the fluorination mechanism
}

Tressaud A., Shirasaki T., Nansé G., Papirer E.

Published in Carbon 2002, vol. 40, n², p. 217-220.

\begin{abstract}
:
The effect of fluorination, using $\mathrm{CF}_{4}$ r.f. plasmas, has been studied on three different types of carbon blacks: a thermal black, a furnace black and a high electrical conducting black. The influences of the morphology and structure of the three blacks on the fluorination mechanism have been investigated. In particular, the ratio Type I/Type II structures (i.e., surface (CF) and border groups of graphitic domains with $\mathrm{sp}^{2} \mathrm{C} /$ polyalicyclic perfluorinated structures with $\mathrm{sp}^{3} \mathrm{C}$ ), has been correlated to the microstructural organisation. The transformation into Type II structures is more easily achieved in highly accessible XE2 blacks, whereas in materials with lower crystallinity (MT), the presence of numerous defects leads preferentially to surface $\left(\mathrm{CF}_{\mathrm{x}}\right)$ perfluorinated groups.
\end{abstract}

\section{Introduction}

Carbon blacks, with large surface areas, fix significant amounts of fluorine atoms when treated, at low temperature, with fluorine gas [1]. Several types of carbon blacks do exist and their characteristics, such as specific surface area, surface structure, etc., greatly affect the fluorination reaction.

In this instance, we used $\mathrm{CF}_{4}$ r.f. plasma for the fluorination of carbon blacks and investigated, by $\mathrm{X}$-ray photoelectron spectroscopy (XPS), the influence on the fluorination process of both plasma treatment parameters and characteristics of carbon blacks.

\section{Experimental}

\subsection{Carbon black fluorination}

Three types of carbon blacks with different surface areas (SA) were selected: a thermal black (MT-N990, SA $=8 \mathrm{~m}^{2} \mathrm{~g}^{-}$ $\left.{ }^{1}\right)$, a furnace black (N115, SA $=145 \mathrm{~m}^{2} \mathrm{~g}^{-1}$ ) and a highly electrical conducting black $\left(X E-2, \mathrm{SA}=1000 \mathrm{~m}^{2} \mathrm{~g}^{-1}\right)$.

The fluorination in r.f. plasma conditions was carried out in a SE-80 barrel reactor (Plasma Tech. System). $\mathrm{CF}_{4}$ gas was excited by a r.f. source at $13.56 \mathrm{MHz}$. The experimental parameters, that may be adjusted during the fluorination process, fully described in previous papers, are: the inlet gas composition (pure $\mathrm{CF}_{4}$ in this case); the inlet gas flow (between 8 and $16 \mathrm{~cm}^{3} \mathrm{~min}^{-1}$ ); the total pressure (between 25 and 200 mTorr); the r.f. power (between 40 and 110 W); the reaction duration (between 10 and $300 \mathrm{~min}$ ) [1], [2] and [3].

\subsection{XPS analysis of fluorinated carbon blacks}

The XPS analyses were performed on a Leybold LHS11 spectrometer. The ionizing radiation $(\mathrm{Ka} \mathrm{Mg})$ was provided by a non-monochromatic X-ray source working at an acceleration of $10 \mathrm{kV}$ and an emission current of $30 \mathrm{~mA}$. Information concerning the spectrometer and the experimental details have been previously reported [2], as well as the fitting procedure of $\mathrm{C}$ 1s and $\mathrm{F}$ 1s envelopes.

\section{Results and discussion}

\subsection{Assignment of $C$ 1s and F 1s components of XPS spectra}

The shape of the $\mathrm{C}$ 1s envelopes does not appreciably differ for the three fluorinated carbon blacks but the relative intensities of the different components vary significantly. An example of $\mathrm{C} 1 \mathrm{~s}$ and $\mathrm{F} 1 \mathrm{~s}$ envelopes of fluorinated N115 carbon black is given in Fig. 1 (r.f. plasma-fluorination conditions: $\mathrm{CF}_{4}$ gas at a flow rate of $8 \mathrm{~cm}^{3} \mathrm{~min}^{-1}$, with a total pressure $p=200 \mathrm{mTorr}$ under a r.f. power of $80 \mathrm{~W}$ during $60 \mathrm{~min}$ ). The five components corresponding to $C$ covalently linked to $\mathrm{F}(\mathrm{C}-\mathrm{F}$ bonds)are denominated $\mathrm{C} 1 \mathrm{~s}(6)$ to $\mathrm{C} 1 \mathrm{~s}(10)$ components. They are located at higher binding energies 
comparatively to the $\mathrm{C}$ 1s peak corresponding to non-functionalized sp2 and sp3 $\mathrm{C}$ atoms that are not affected by fluorination $\left(C 1 \mathrm{~s}(1)\right.$ at a binding energy $\left.E_{b}=284.5 \mathrm{eV}\right)$. This latter peak is taken as an internal reference for the measure the energy shifts of the other components. In between $C 1 \mathrm{~s}(1)$ and $C 1 \mathrm{~s}(6)$, four components can be assigned to $C$ atoms that are not directly bound to $F$ atoms. The $E_{b}$ shift is due to an inductive effect which is dependent on the number of $F$ atoms in $\beta$ position of a given $C$ atom, that are bound to his first $C$ neighbor. The shift can be evaluated to about $0.6 \pm 0.2 \mathrm{eV}$ for each $\mathrm{F}$ atom and is approximately additive. In the case of the $\mathrm{F}$ is spectrum, the chemical shift of the $F$ 1s core level is less dependent on the $x$ value of $C F_{x}$ groups and therefore the $E_{b}$ shift is more limited.

Depending on the nature of the carbon conformation, two main types of $C-F$ bonding have been observed. In the $C$ is spectra, the peak at $288.6 \mathrm{eV}(\mathrm{C} 1 \mathrm{~s}(6))$, which is the most important component of $\mathrm{C}-\mathrm{F}$ bonds, can be assigned to carbon atoms present at the surface and border of the graphitic domains which are covalently bound to fluorine atoms without any change in their $\mathrm{sp}^{2}$ conformation (Type I structures). In the $\mathrm{F}$ 1s envelope the component corresponding to Type 1 structure is $F 1 \mathrm{~s}(6)$, which is located at $E_{b}=687.6 \mathrm{eV}$. This component has been taken as an internal reference for the $F 1 s$ binding energy shifts. In the $C 1$ s envelope, at higher binding energies, i.e., for $E_{b} \geq 290 \mathrm{eV}, C$ $1 \mathrm{~s}(8)$ to $\mathrm{C} 1 \mathrm{~s}(10)$ contributions of polyalicyclic perfluorinated structures, in which the $\mathrm{sp}^{3} \mathrm{C}$ skeleton forms puckered layers, are similar to those of covalent graphite fluorides (CF) ${ }_{n}$ (Type II structures). F atoms of this second type of C$F$ bonds contribute to the components (8) to (10) of $F$ 1s envelope, with $E_{b} \geq 690 \mathrm{eV}$. The assignment of the different components of $\mathrm{C} 1 \mathrm{~s}$ and $\mathrm{F} 1 \mathrm{~s}$ XPS spectra in the case of a N115 carbon black are proposed in Table 1 and Table 2.

\subsection{I nfluence of the carbon black morphology on the fluorination process.}

The relative amount of Type II structures can be directly deduced from the ratio of the surface area (A) of components $F$ 1s $(i \geq 8)$ to the total $F$ is surface of the $F$ 1s envelope, i.e., $A(F 1 s(i \geq 8)) / A(F 1 s($ total $))$. This ratio increases regularly from MT to XE2 fluorinated samples, as shown in Fig. 2. On the other hand, the ratio $A(F$ $1 \mathrm{~s}($ total $)) / \mathrm{A}(\mathrm{C} 1 \mathrm{~s}(\mathrm{i} \geq 6))$ gives an idea of the relative importance of perfluorinated $\mathrm{CF}_{\mathrm{x}}$ groups: for normalized $\mathrm{F}$ 1s and $\mathrm{C} 1 \mathrm{~s}$ areas, these functional groups would have a (CF) composition when this ratio is equal to one. It can be noted from Fig. 2 that this ratio decreases following the sequence MT>N115>XE2. Consequently, in the case of MT thermal black, only a small number of Type II structures are formed, whereas the ratio F/C is larger than those of N115 or $\mathrm{XE2}$. This means that, owing to its lower structural organization, the proportion of border $\mathrm{sp}^{2} \mathrm{C}$ and of protonated $\mathrm{sp}^{3} \mathrm{C}$ is much higher in the volume explored by XPS in thermal black than in the other blacks. For a higher structural organisation of the material, e.g., for XE-2 black, the proportions are reversed: higher amount of Type II structures and lower amount of $\mathrm{CF}_{x}$ fluorinated functional groups. In this latter case, the formation of polyalicyclic (CF) $n$ units similar to covalent graphite fluorides is enhanced because of a greater accessibility of carbon atoms by fluorine, which may yield locally exothermic reactions.

\subsection{Fluorination mechanisms}

Some insight on the fluorination mechanism can also be obtained from the dependence of $F / C$ ratios with the reaction duration: $A(F$ 1s (total $)) / A(C$ 1s(total $))$ ratio from XPS measurements which gives the surface composition, and $F / C$ ratio from elemental analysis which accounts for a bulk composition. The result is illustrated in Fig. 3 by comparing the behavior of $\mathrm{N} 115$ and $\mathrm{XE2}$. In the case of $\mathrm{XE}-2,[\mathrm{~F} / \mathrm{C}]_{\mathrm{XPS}}$ approaches $[\mathrm{F} / \mathrm{C}]_{\mathrm{EA}}$ as the plasma reaction duration is increased, to finally reach almost equality for about $60 \mathrm{~min}$. This means that $\mathrm{F}$ atoms should be homogeneously bound to carbon atoms in the core. This result again may be related to the particular morphology of XE-2, i.e., to its highly accessible surface area. On the contrary, in the case of $N 115$, the ratio $[\mathrm{F} / \mathrm{C}]_{\mathrm{XPS}} /[\mathrm{F} / \mathrm{C}]_{\mathrm{EA}}$ increases with the reaction duration, which means that $\mathrm{F}$ atoms dominantly exist in the superficial area with perfluorinated $\mathrm{CF}_{\mathrm{x}}$ groups leaving unaltered carbon cores.

\section{Conclusion}

This study clearly demonstrates the major influence of the carbon black origin and of the microstructural organisation of the material on the fluorination mechanism. When carbon sites are highly accessible, i.e., in XE2 carbon blacks, the transformation into covalent graphite fluoride type (Type II structures) is more easily achieved. On the other hand, for materials with lower crystallinity, for instance MT carbon blacks, the presence of numerous defects leads preferentially to surface $\left(\mathrm{CF}_{\mathrm{x}}\right)$ perfluorinated groups. Conversely, a careful examination of the behavior of carbon blacks towards fluorine reactivity could lead to a better approach of the structure of pristine material, in the light of our present knowledge. 


\section{References}

1. Moguet F. PhD Thesis, Université Bordeaux 1, France, 1996.

2. (a) G. Nansé, E. Papirer, P. Fioux, F. Moguet, A. Tressaud, Carbon, 35 (1997), pp. 175-194. (b) G. Nansé, E. Papirer, P. Fioux, F. Moguet, A. Tressaud, Carbon, 35 (1997), pp. 371-388. (c) G. Nansé, E. Papirer, P. Fioux, F. Moguet, A. Tressaud, Carbon, 35 (1997), pp. 515-518.

3. T. Shirasaki, F. Moguet, L. Lozano, A. Tressaud, G. Nansé, E. Papirer, Carbon, 37 (1999), pp. 1891-1900. 
Table 1

Energy shifts and assignments of the different components of $\mathrm{C} 1 \mathrm{~s}$ spectra of plasma-fluorinated furnace carbon black (non-activated N115) $\left(E_{\mathrm{b}}(\mathrm{C} 1 \mathrm{~s}(1))=284.5 \mathrm{eV}\right)$

\begin{tabular}{|c|c|c|}
\hline Component & $\begin{array}{l}\Delta \mathrm{C}(\mathrm{i})-\mathrm{C}(1) \\
(\mathrm{eV})\end{array}$ & Assignment \\
\hline$C(1)$ & - & $\begin{array}{l}\text { Non-functionalized } \mathrm{sp}^{2} \text { and } \mathrm{sp}^{3} \mathrm{C} \text { atoms, not affected } \\
\text { by fluorination }\left(E_{\mathrm{b}}=284.5 \mathrm{eV}\right)\end{array}$ \\
\hline$C(2)$ & 1.0 & $\begin{array}{l}\text { Aliphatic non-functionalized } \mathrm{sp}^{3} \mathrm{C} \text { in a non-fluorinated } \\
\text { environment (areas modified by 'plasma effect') }\end{array}$ \\
\hline$C(3)$ & 1.8 & $\begin{array}{l}\text { Non-functionalized } \mathrm{sp}^{2} \mathrm{C} \text { in } \beta \text { position to one } \mathrm{F} \text { atom } \\
\text { Non-functionalized } \mathrm{sp}^{2} \mathrm{C} \text { or } \mathrm{sp}^{3} \mathrm{C} \text { in } \beta \text { position to one or } \\
\text { two } \mathrm{F} \text { atom(s), respectively } \\
\mathrm{sp}^{2} \mathrm{C} \text { bound to an oxygen atom (phenol, phenyl ether) }\end{array}$ \\
\hline$C(4)$ & 2.6 & $\begin{array}{l}\text { Non-functionalized } \mathrm{sp}^{2} \mathrm{C} \text { or } \mathrm{sp}^{3} \mathrm{C} \text { in } \beta \text { position to two or } \\
\text { three } \mathrm{F} \text { atoms, respectively } \\
\text { Oxygenated } \mathrm{sp}^{3} \mathrm{C} \text { in a non-functionalized environment } \\
\left(\mathrm{CH}_{x}-\mathrm{OH} \text {, or } \mathrm{C}-\mathrm{O}-\mathrm{C}\right)\end{array}$ \\
\hline$C(5)$ & $\begin{array}{l}3.3 \\
\pm 0.1\end{array}$ & $\begin{array}{l}\text { Oxygenated } \mathrm{sp}^{3} \mathrm{C} \text { in } \beta \text { position to a } \mathrm{F} \text { atom } \\
\text { Non-functionalized } \mathrm{sp}^{3} \mathrm{C} \text { in } \beta \text { position to at least three } \mathrm{F} \text { atoms } \\
\mathrm{sp}^{2} \mathrm{C} \text { 'semi-ionic', bound to intercalated } \mathrm{F} \text { atom } \\
\text { (very weak contribution) }\end{array}$ \\
\hline $\mathrm{C}(6)$ & $\begin{array}{l}4.2 \\
\pm 0.2\end{array}$ & $\mathrm{sp}^{2} \mathrm{C}$ covalently linked to an $\mathrm{F}$ atom in Type I structure \\
\hline$C(7)$ & $\begin{array}{l}5.4 \\
\pm 0.3\end{array}$ & $C F$ groups of Type I structure in $\beta$ position of $\mathrm{CF}_{2}$ groups \\
\hline$C(8)$ & $\begin{array}{l}6.3 \\
\pm 0.4\end{array}$ & $\begin{array}{l}\mathrm{CF}_{2} \text { groups of Type I structure } \\
\mathrm{CF} \text { groups of Type II structure }\end{array}$ \\
\hline$C(9)$ & $\begin{array}{l}7.9 \\
\pm 0.4\end{array}$ & $\begin{array}{l}\mathrm{CF}_{3} \text { groups of Type I structure } \\
\mathrm{CF}_{2} \text { groups of Type II structure }\end{array}$ \\
\hline$C(10)$ & $\begin{array}{l}9.6 \\
\pm 0.4\end{array}$ & $\begin{array}{l}\mathrm{CF}_{3} \text { groups of Type II structure (very weak component) } \\
\text { Plasmon }\end{array}$ \\
\hline
\end{tabular}

Table 2

Energy shifts and assignments of the different components of F 1s spectra of plasma-fluorinated furnace carbon black (non-activated N115) $\left(E_{\mathrm{b}}(\mathrm{C} 1 \mathrm{~s}(1))=284.5 \mathrm{eV}\right)$

\begin{tabular}{lll}
\hline Component & $\begin{array}{l}\Delta \mathrm{F}(\mathrm{i})-\mathrm{F}(6) \\
(\mathrm{eV})\end{array}$ & Assignment \\
\hline $\mathrm{F}(6)$ & - & $\mathrm{F}$ atoms in Type I structure $\left(E_{\mathrm{b}}=687.6 \mathrm{eV}\right)$ \\
$\mathrm{F}(8)$ & 2.0 & $\mathrm{~F}$ atoms in Type II structure \\
& \pm 0.1 & \\
$\mathrm{~F}(9)$ & 3.5 & F atoms in Type II structure with charge effect \\
& \pm 0.1 & \\
$\mathrm{~F}(10)$ & 5.9 & $\begin{array}{l}\text { F atoms in Type II structure with higher charge } \\
\text { effect (very weak component) }\end{array}$ \\
\hline
\end{tabular}



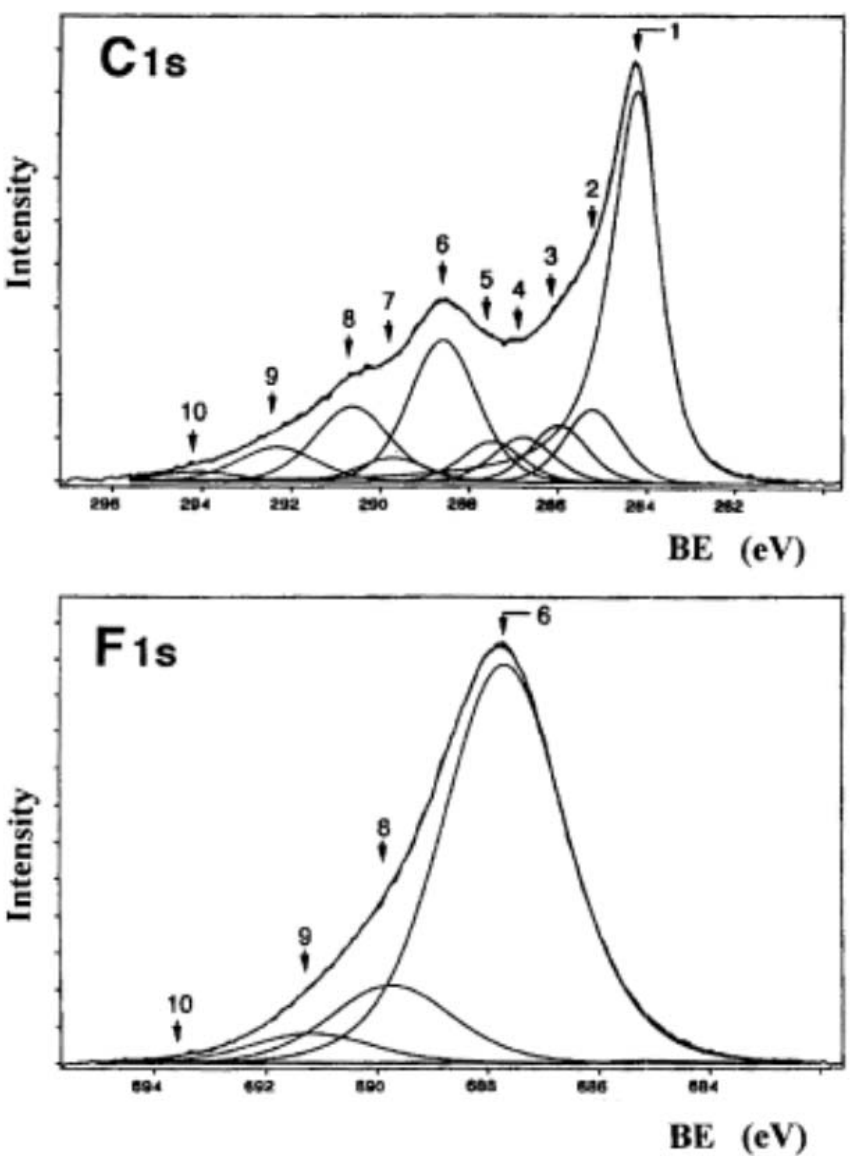

Fig. 1. Fitted high resolution C 1s and F 1s XPS spectra of plasma-fluorinated N115 furnace carbon black.

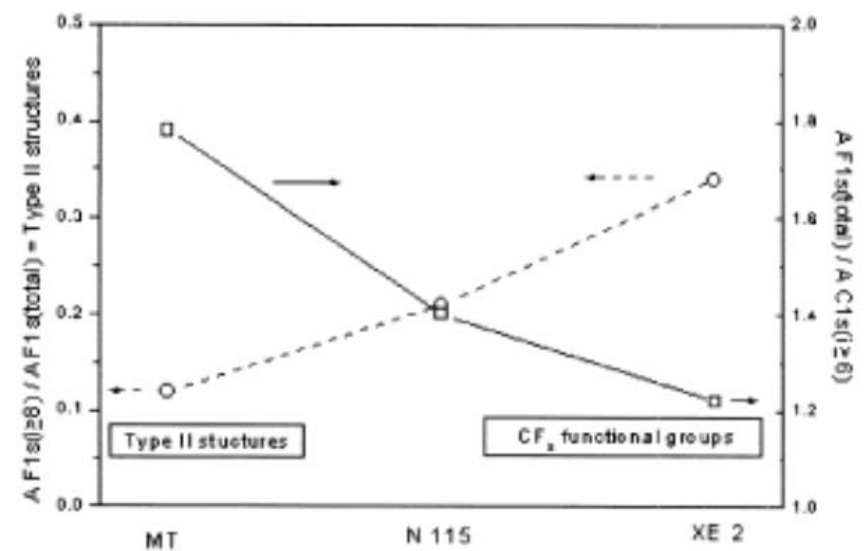

Fig. 2. Relative amounts of Type II structures and perfluorinated $\mathrm{CF}_{x}$ groups in different fluorinated carbon blacks. 


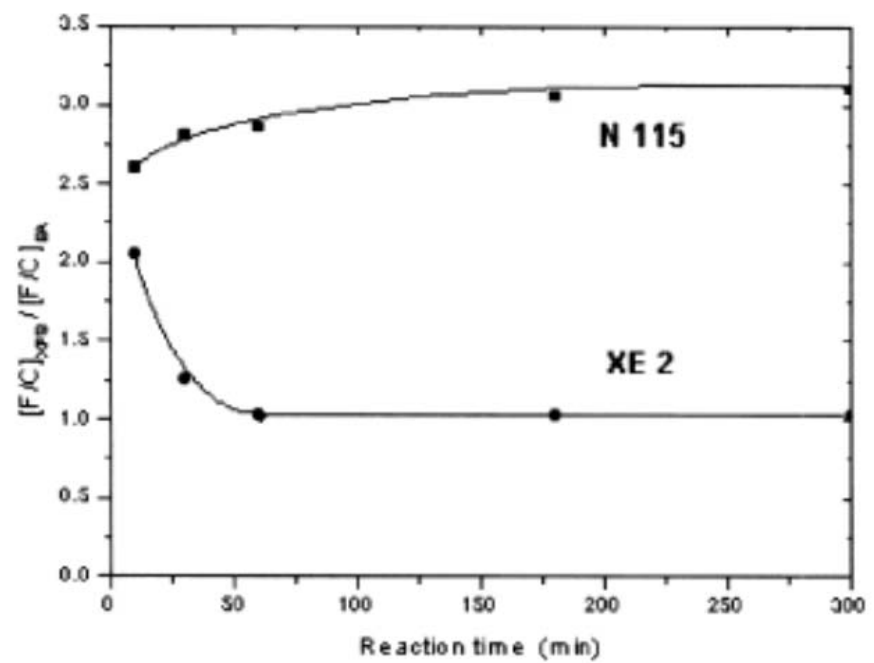

Fig. 3. Reaction time dependence of the $[\mathrm{F} / \mathrm{C}]_{\mathrm{XPS}} /[\mathrm{F} / \mathrm{C}]_{\mathrm{EA}}$ ratio for N115 and XE2 carbon blacks. 